\title{
Proposal of a Mathematics Pilot Program for Engineering Students from Vulnerable Groups of Escuela Politécnica Nacional
}

\author{
Iván Sandoval, M.Sc ${ }^{1}$, Tarquino Sánchez, $\mathrm{MBA}^{2}$, David Naranjo, Eng. ${ }^{3}$, and Angélica Jiménez, Eng. ${ }^{4}$ \\ 1, 2, 3,4 Escuela Politécnica Nacional, Ecuador, \\ 1ivan.sandoval@epn.edu.ec, ${ }^{2}$ tarquino.sanchez@epn.edu.ec, ${ }^{3}$ david.naranjo@epn.edu.ec, ${ }^{4}$ andrea.jimenez01@epn.edu.ec
}

\begin{abstract}
Since 2017, Secretaría Nacional de Educación Superior, Ciencia, Tecnología e Innovación (SENESCYT), has included, among the new students entering the Leveling Course of Escuela Politécnica Nacional (EPN), those from Affirmative Action population segment. These students tend to show low academic performance and high dropping out rates.
\end{abstract}

Mathematics, of considerable importance for engineering training, is the subject that shows the lowest indicator of academic performance during high school, for this reason, EPN in response to this problem, proposes a Mathematics Pilot Program for students of engineering from vulnerable groups. To this end, it was conducted a descriptive analysis of the information of students enrolled in the Leveling Course between the semesters 2017-A and 2018-A, and based on the criteria of the teachers of the Leveling Course, a diagnostic test was designed and applied to the new students of the 2018-B semester, this test evaluated only basic Mathematics.

It was determined that the students from Affirmative Action group presented low passing rate and high dropping out rate during the semesters under study, likewise, students of Affirmative Action group got a low average score in the diagnostic test which evidences poor academic level of these students prior to entering the Leveling Course. In this sense, it is proposed that the pilot program should be structured in 6 units, with special emphasis on Geometry and Trigonometry, and real-valued functions. It is recommended that the pilot program should be implemented as a course prior to the Leveling Course, so that the Government's Affirmative Action program fulfills its mission of effectively including students from vulnerable groups in the Higher Education System

Keywords - Vulnerable Groups, Affirmative Action, Academic Pilot Program, Diagnostic Test, Dropping Out, Academic Performance.

\section{INTRODUCTION}

In Ecuador, Secretaría Nacional de Educación Superior, Ciencia, Tecnología e Innovación (SENESCYT) is the body that regulates the admission process to Higher Education Institutions (HEIs).

During the admission process, an applicant to a HEI must meet some requirements, such as taking the National Exam of Educational Evaluation "Ser Bachiller" and filling out the

Digital Object Identifier (DOI):

http://dx.doi.org/10.18687/LACCEI2019.1.1.387

ISBN: 978-0-9993443-6-1 ISSN: 2414-6390
Associated Factors Survey. Although there is no minimum score established to apply for a career in a HEI (due to the fact that it varies in each admission process for a particular HEI), the allocation of places is automatically made according to the application score, the availability of places in each HEI and the demand that exists for a career in a given period; in the main, applicants who get the highest scores in the exam are more likely to get a place [1]. However, in 2014, SENESCYT implemented an affirmative action policy that would expand access to Higher Education for applicants in situation of economic and social vulnerability, through the Affirmative Action Program [2], in this way, an applicant who has been included in the Affirmative Action Program can apply preferentially to $15 \%$ of the academic places offered by public HEIs, even if their application score has not met the minimum required to access to a specific IES during a specific admission process [1], [3], [4].

The determination of the beneficiaries of the Affirmative Action Program is achieved through the analysis of each applicant's self-declared information in the Associated Factors Survey, as a result of this analysis, it is calculated a vulnerability index whose lowest values correspond to those applicants from historically excluded groups, to those who have some type of disability or to those who are placed in the lowest decile according to their socioeconomic status; in this way, applicants whose characteristics show that they are in a situation of greater vulnerability are usually assigned to the Affirmative Action population segment[3].

Since 2017, SENESCYT has included, among the new students entering the Leveling Course of Escuela Politécnica Nacional (EPN), those from the Affirmative Action population segment. It was noticed that their average application score (758/1000) was lower than that obtained by those from the other population segments $(839 / 1000)$, which denoted poor previous academic preparation [2].

During the first year of studies, students from vulnerable groups generally show lower academic performance, compared with that of their peers from the other population segments. Additionally, during high school, Mathematics shows the lowest indicator of academic performance, students perceive Mathematics as complicated which generates

$17^{\text {th }}$ LACCEI International Multi-Conference for Engineering, Education, and Technology: "Industry, Innovation, And Infrastructure for Sustainable Cities and Communities", 24-26 July 2019, Jamaica. 
insecurity and uncertainty in them [5], [6], [7]. According to Instituto Nacional de Evaluación Educativa del Ecuador in the last exam "Ser Bachiller", Mathematics showed the lowest average score above the global average score of all the subjects evaluated [8]. This is a factor of considerable interest, since Mathematics is a fundamental science in the training of engineers due to the fact that its application develops analytical thinking which involves mental agility, rational thinking and problem solving. It also constitutes the basis for understanding technology and other subjects such as Geometry [9].

In addition, students in vulnerable situations are more likely to leave HEIs; factors such as lack of funding, lack of scholarship programs for students, lack of vocational guidance, inadequate previous academic preparation in schools and lack of pedagogical updating of teachers contribute to dropping out[10]. According to [10], two types of dropout can be identified among university students, respect to time (initial, early and late) and respect to space (institutional, internal and the educational system), in addition [11] presents the following concepts:

Premature dropout: the case in which a student having been admitted to the university does not enroll.

Early dropout: the case in which a student drops out during the first semesters.

Late dropout: the case in which a student drops out during the last semesters.

In 2017, EPN carried out an academic accompaniment program for students from vulnerable groups, which was developed in parallel with the regular classes of the Leveling Course. This program contemplated the topics that are studied in these subjects: Mathematics, Geometry, Physics and Chemistry of the Leveling Course. Although the students who participated in this program improved their academic performance, this improvement was not enough to pass the Leveling Course [12].

In view of the above and in response to the described problem, the aim of the present study was to propose a pilot program of Mathematics for Engineering students from vulnerable groups, prior to the Leveling Course of the EPN.

\section{METHODOLOGY}

\section{A. Descriptive Analysis}

A descriptive analysis was made for the 4136 new students enrolled in the EPN during the semesters 2017-A, 2017-B and 2018-A; for this analysis, the information about passing and dropping out rates was considered according to the population segment to which they belonged. The information was processed in Excel and was obtained from databases of SENESCYT and Dirección de Gestión de la Información of the EPN (DGIP).

\section{B. Diagnostic test}

A survey process was carried out to 11 teachers from the Leveling Course who teach the different subjects, with the objective of identifying, according to their criteria, the topics in which students usually present the biggest flaws and academic difficulties. It should be noted that the topics on which they were investigated were not those concerning the curriculum of the Leveling Course, but rather those subjects considered by teachers as elementary knowledge that students should master so that their performance in each of the subjects was optimal. Once these topics were identified, they were compared with the subjects studied by the students during the Higher Level of General Basic Education (HLGBE) and during high school, and a syllabus was elaborated in which the previous knowledge that students should have to achieve a good academic performance was specified. From this syllabus, questions were developed to collect information about students' academic aptitudes and a diagnostic test was designed through which those aptitudes were evaluated.

The new students from Affirmative Action population segment of 2018-B semester were established as the target population. For the process of applying the diagnostic test, students of the General Population were also evaluated so that they constituted the control group. With the information resulting from the diagnostic test, a descriptive analysis was carried out in Excel.

C. Determination of performance rate according to each topic and unit evaluated in the diagnostic test

First, the topics that were evaluated in the test were determined according to the originally proposed syllabus. Then, each exercise proposed in the diagnostic test was related to the evaluated subject and, for each exercise, a global score of 1 point was given, which allowed, subsequently, to calculate the performance rate for each topic. Due to the fact that some exercises evaluated more than one subject simultaneously, a weighting was performed over 1 , thus, for this type of exercises, values closer to 1 indicate more emphasis on a specific topic, yet the global score for this type of exercises will not be greater than 1 . For the calculation of the performance rate based on each topic evaluated (PRTE), the results were grouped by population segments, then multiplied the number of correct answers (for the same exercise) for each weighted score, this process was repeated for each exercise, in this way, subtotals were obtained for each item evaluated for each exercise. Finally, the subtotals were added for each specific topic and divided for the maximum weighted score that could be obtained in the test, thus obtaining the PRTE. Subsequently, with the results obtained, a comparative analysis was carried out in SPSS at a significance level of 0.05 between

$17^{\text {th }}$ LACCEI International Multi-Conference for Engineering, Education, and Technology: "Industry, Innovation, And Infrastructure for Sustainable Cities and Communities", 24-26 July 2019, Jamaica. 
the results obtained from the students of Affirmative Action and General Population.

Based on the results of the PRTE, each topic was grouped by units and a weighting of these values was carried out again only for Affirmative Action population segment, thus obtaining the performance rate according to each unit evaluated (PRUE) which was an indicator about the emphasis that should be made in each unit when implementing the pilot program of Mathematics for engineering students from vulnerable groups of EPN.

\section{RESULTS}

\section{A. Descriptive Analysis}

In Fig. 1 it can be seen that of the total number of students enrolled between the semesters 2017-A and 2018-A, on average, $94.71 \%$ corresponded to General Population while the remaining $5.29 \%$ belonged to Affirmative Action population segment. According to Table I, it is observed that the passing rate of the students of Affirmative Action was lower than that of the rest of students, except in the cases of third enrollment for the semester 2017-A and first enrollment for 2018-A, however, for these cases in particular, the differences between the passing rates are not at all contrasting as in the rest of the cases.

Initial dropout, presented in Table II, refers to those cases in which the students, to whom SENESCYT assigned a place in EPN through the Third Level Matrix (TLM), did not meet the internal requirements validated by the DGIP and therefore could not enroll in the aforementioned HEI.

On the other hand, Table III presents data on premature dropout. Table IV shows data on inter-semester dropout, which corresponds to those cases in which students who failed the Leveling Course did not enroll the following academic semester.

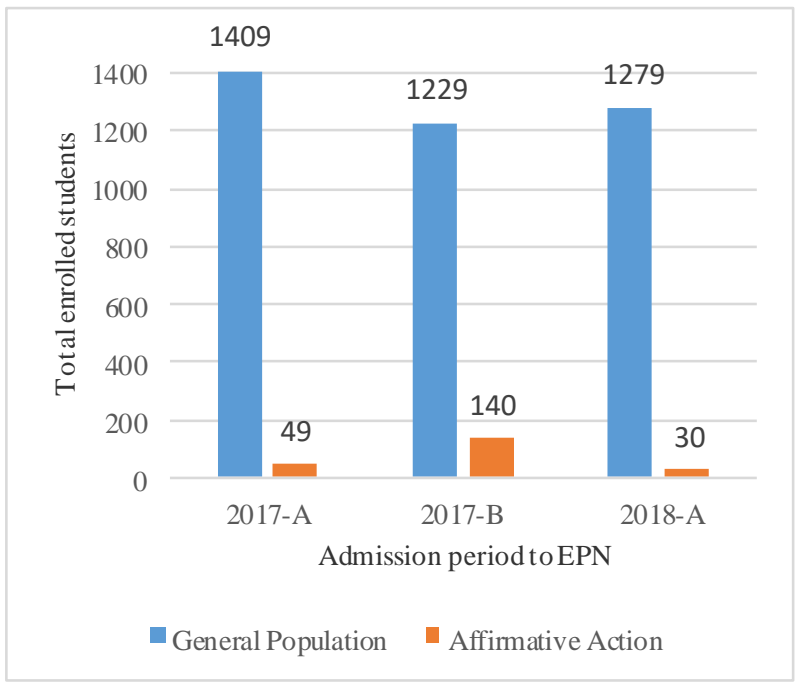

Fig. 1 Total enrolled students at EPN grouped by population segment

which refers to the sum of all types of dropping out, the corresponding percentage was calculated respect to the total number of students considered in the TLM for the respective period of admission to EPN.

For all cases, except for the case of third enrollment in 2017-A, it was evident that the students from Affirmative Action had higher dropping out rates than the students of the General Population.

\section{B. Diagnostic test}

The total number of newly admitted students to EPN for the semester 2018-B was 1414, of which 140 were from Affirmative Action population segment and the remaining 1274 belong to General Population.

TABLE I

PASSING RATE FOR SEMESTERS 2017-A, 2017-B AND 2018-A

\begin{tabular}{|c|c|c|c|c|c|c|c|c|c|c|}
\hline \multirow{2}{*}{$\begin{array}{c}\text { Admission } \\
\text { Period to EPN }\end{array}$} & \multirow{2}{*}{$\begin{array}{l}\text { Population } \\
\text { Segment }\end{array}$} & \multicolumn{3}{|c|}{ First Enrollment } & \multicolumn{3}{|c|}{ Second Enrollment } & \multicolumn{3}{|c|}{ Third Enrollment } \\
\hline & & $\begin{array}{c}\text { Enrolled } \\
\text { students }\end{array}$ & $\begin{array}{c}\text { Passing } \\
\text { Students }\end{array}$ & $\begin{array}{c}\text { Passing } \\
\text { rate }\end{array}$ & $\begin{array}{l}\text { Enrolled } \\
\text { students }\end{array}$ & $\begin{array}{l}\text { Passing } \\
\text { Students }\end{array}$ & $\begin{array}{c}\text { Passing } \\
\text { rate }\end{array}$ & $\begin{array}{l}\text { Enrolled } \\
\text { students }\end{array}$ & $\begin{array}{l}\text { Passing } \\
\text { Students }\end{array}$ & $\begin{array}{c}\text { Passing } \\
\text { rate }\end{array}$ \\
\hline \multirow{2}{*}{ 2017-A } & $\begin{array}{c}\text { General } \\
\text { Population }\end{array}$ & 1409 & 232 & $16.47 \%$ & 958 & 367 & $38.31 \%$ & 212 & 106 & $50.00 \%$ \\
\hline & $\begin{array}{c}\text { Affirmative } \\
\text { Action }\end{array}$ & 49 & 2 & $4.08 \%$ & 33 & 3 & $9.09 \%$ & 8 & 5 & $62.50 \%$ \\
\hline \multirow{2}{*}{ 2017-B } & $\begin{array}{c}\text { General } \\
\text { Population }\end{array}$ & 1229 & 192 & $15.62 \%$ & 746 & 285 & $38.20 \%$ & - & - & - \\
\hline & $\begin{array}{c}\text { Affirmative } \\
\text { Action }\end{array}$ & 140 & 5 & $3.57 \%$ & 79 & 15 & $18.99 \%$ & - & - & - \\
\hline \multirow{2}{*}{ 2018-A } & $\begin{array}{c}\text { General } \\
\text { Population }\end{array}$ & 1279 & 80 & $6.25 \%$ & - & - & - & - & - & - \\
\hline & $\begin{array}{c}\text { Affirmative } \\
\text { Action }\end{array}$ & 30 & 2 & $6.67 \%$ & - & - & - & - & - & - \\
\hline
\end{tabular}

$17^{\text {th }}$ LACCEI International Multi-Conference for Engineering, Education, and Technology: "Industry, Innovation, And Infrastructure for Sustainable Cities and Communities", 24-26 July 2019, Jamaica. 
TABLE II

INITIAL DROPOUT FOR SEMESTERS 2017-A, 2017-B AND 2018-A

\begin{tabular}{|c|c|c|c|c|c|}
\hline \multirow{2}{*}{$\begin{array}{c}\text { Admission } \\
\text { Period to EPN }\end{array}$} & $\begin{array}{c}\text { Population } \\
\text { Segment }\end{array}$ & TLM & DGIP & $\begin{array}{c}\text { Initial } \\
\text { Dropout }\end{array}$ & $\begin{array}{c}\text { Initial } \\
\text { Dropout } \\
\text { rate }\end{array}$ \\
\hline \multirow{2}{*}{$2017-\mathrm{A}$} & $\begin{array}{c}\text { General } \\
\text { Population }\end{array}$ & - & $* 575$ & 0 & - \\
\cline { 3 - 6 } & $\begin{array}{c}\text { Affirmative } \\
\text { Action }\end{array}$ & 60 & 58 & 2 & $3.33 \%$ \\
\hline \multirow{2}{*}{$2017-\mathrm{B}$} & $\begin{array}{c}\text { General } \\
\text { Population }\end{array}$ & 1359 & 1232 & 127 & $9.35 \%$ \\
\cline { 2 - 6 } & $\begin{array}{c}\text { Affirmative } \\
\text { Action }\end{array}$ & 166 & 141 & 25 & $15.06 \%$ \\
\hline & $\begin{array}{c}\text { General } \\
\text { Population }\end{array}$ & 1440 & 1311 & 129 & $8.96 \%$ \\
\cline { 2 - 6 } & $\begin{array}{c}\text { Affirmative } \\
\text { Action }\end{array}$ & 40 & 33 & 7 & $17.50 \%$ \\
\hline
\end{tabular}

*These students come from the transition semester, in which it was considered that all of them enrolled for the first time.

TABLE III

PREMATURE DROPOUT FOR SEMESTERS 2017-A, 2017-B AND 2018-A

\begin{tabular}{|c|c|c|c|c|c|}
\hline $\begin{array}{c}\text { Admission } \\
\text { Period to } \\
\text { EPN }\end{array}$ & $\begin{array}{c}\text { Population } \\
\text { Segment }\end{array}$ & DGIP & $\begin{array}{l}\text { Enrolled } \\
\text { students }\end{array}$ & $\begin{array}{c}\text { Premature } \\
\text { Dropout }\end{array}$ & $\begin{array}{c}\text { Premature } \\
\text { Dropout } \\
\text { rate }\end{array}$ \\
\hline \multirow{3}{*}{ 2017-A } & \multirow{2}{*}{$\begin{array}{c}\text { General } \\
\text { Population }\end{array}$} & $* 575$ & 575 & 0 & $0.00 \%$ \\
\hline & & 872 & 834 & 38 & $4.36 \%$ \\
\hline & $\begin{array}{c}\text { Affirmative } \\
\text { Action }\end{array}$ & 58 & 49 & 9 & $15.52 \%$ \\
\hline \multirow{2}{*}{ 2017-B } & $\begin{array}{c}\text { General } \\
\text { Population }\end{array}$ & 1232 & 1229 & 3 & $0.24 \%$ \\
\hline & $\begin{array}{c}\text { Affirmative } \\
\text { Action }\end{array}$ & 141 & 140 & 1 & $0.71 \%$ \\
\hline \multirow{2}{*}{ 2018-A } & $\begin{array}{c}\text { General } \\
\text { Population }\end{array}$ & 1311 & 1279 & 32 & $2.44 \%$ \\
\hline & $\begin{array}{l}\text { Affirmative } \\
\text { Action }\end{array}$ & 33 & 30 & 3 & $9.09 \%$ \\
\hline
\end{tabular}

*These students come from the transition semester, in which it was considered that all of them enrolled for the first time.
Independently of the subject that teachers impart, they agreed in which students show the greater failures in the topics relative to Mathematics, consequently, it was determined that this will be the subject that would be evaluated in the diagnostic test. Additionally, in Fig. 2 it can be seen that $91 \%$ of the teachers surveyed agreed that the Mathematics topics to be evaluated in the diagnostic test should only consider those related to the HLGBE and not the topics of high school.

The diagnostic test consisted of 65 multiple choice items which evaluated the topics: operations with real numbers, operations with polynomials, special products and factorization, equations and inequations, real-valued functions and Geometry and Trigonometry.

Table VI shows that, in general, students' scores were below the minimum required $(70 \%)$ to pass the exam. Only $13 \%$ of students from Affirmative Action and 14\% from the General Population obtained a performance higher than $70 \%$.

Additionally, the average score in the Diagnostic Test of the students of the Affirmative Action (26/65) was lower than that obtained by those of the General Population (33/65), which reflects, in the first instance, a lower academic level for students of vulnerable groups, however, in general, the performance for the two groups of students was low, even more if considering that the diagnostic test evaluated knowledge of HLGBE.

C. Determination of performance rate according to each topic and unit evaluated in the diagnostic test

In Fig. 3 it is observed that students of Affirmative Action obtained a lower PRTE than that obtained by their peers from General Population in 43 of the 53 topics evaluated, which evidences the deficient previous academic formation of the students coming from vulnerable groups.

TABLE IV

INTER-SEMESTER DROPOUT FOR SEMESTERS 2017-A, 2017-B AND 2018-A

\begin{tabular}{|c|c|c|c|c|c|c|c|c|c|c|}
\hline \multirow[b]{2}{*}{$\begin{array}{c}\text { Admission } \\
\text { Period to } \\
\text { EPN }\end{array}$} & \multirow[b]{2}{*}{$\begin{array}{c}\text { Population } \\
\text { Segment }\end{array}$} & \multicolumn{3}{|c|}{ First Enrollment } & \multicolumn{3}{|c|}{ Second Enrollment } & \multicolumn{3}{|c|}{ Third Enrollment } \\
\hline & & $\begin{array}{l}\text { Enrolled } \\
\text { students }\end{array}$ & $\begin{array}{c}\text { Inter- } \\
\text { semester } \\
\text { drop out }\end{array}$ & $\begin{array}{c}\text { Inter- } \\
\text { semester } \\
\text { dropout rate }\end{array}$ & $\begin{array}{l}\text { Enrolled } \\
\text { students }\end{array}$ & $\begin{array}{c}\text { Inter- } \\
\text { semester } \\
\text { drop out }\end{array}$ & $\begin{array}{c}\text { Inter- } \\
\text { semester } \\
\text { dropout rate }\end{array}$ & $\begin{array}{l}\text { Enrolled } \\
\text { students }\end{array}$ & $\begin{array}{c}\text { Inter- } \\
\text { semester } \\
\text { dropout }\end{array}$ & $\begin{array}{c}\text { Inter- } \\
\text { semester } \\
\text { dropout rate }\end{array}$ \\
\hline \multirow{3}{*}{ 2017-A } & \multirow{2}{*}{$\begin{array}{c}\text { General } \\
\text { Population }\end{array}$} & $* 575$ & $* 128$ & $22.26 \%$ & $* 244$ & $* 98$ & $40.16 \%$ & $*_{-}$ & $* 0$ & - \\
\hline & & 834 & 91 & $10.91 \%$ & 714 & 281 & $39.36 \%$ & 212 & 106 & $50.00 \%$ \\
\hline & $\begin{array}{c}\text { Affirmative } \\
\text { Action }\end{array}$ & 49 & 14 & $28.57 \%$ & 33 & 22 & $66.67 \%$ & 8 & 3 & $37.50 \%$ \\
\hline \multirow{2}{*}{ 2017-B } & $\begin{array}{c}\text { General } \\
\text { Population }\end{array}$ & 1229 & 291 & $23.68 \%$ & 746 & 442 & $59.25 \%$ & - & - & - \\
\hline & $\begin{array}{c}\text { Affirmative } \\
\text { Action }\end{array}$ & 140 & 56 & $40.00 \%$ & 79 & 61 & $77.22 \%$ & - & - & - \\
\hline \multirow{2}{*}{ 2018-A } & $\begin{array}{c}\text { General } \\
\text { Population }\end{array}$ & 1279 & 269 & $21.03 \%$ & - & - & - & - & - & - \\
\hline & $\begin{array}{c}\text { Affirmative } \\
\text { Action }\end{array}$ & 30 & 16 & $53.33 \%$ & - & - & - & - & - & - \\
\hline
\end{tabular}

*These students come from the transition semester, in which it was considered that all of them enrolled for first time.

$17^{\text {th }}$ LACCEI International Multi-Conference for Engineering, Education, and Technology: "Industry, Innovation, And Infrastructure for Sustainable Cities and Communities”, 24-26 July 2019, Jamaica. 
TABLE V

CUMULATIVE DROPOUT FOR SEMESTERS 2017-A, 2017-B AND

\begin{tabular}{|c|c|c|c|c|}
\hline \multicolumn{5}{|c|}{ 2018-A } \\
\hline $\begin{array}{c}\text { Admission } \\
\text { Period to } \\
\text { EPN }\end{array}$ & $\begin{array}{l}\text { Population } \\
\text { Segment }\end{array}$ & TLM & $\begin{array}{c}\text { Cumulative } \\
\text { Dropout }\end{array}$ & $\begin{array}{l}\text { Cumulative } \\
\text { Dropout rate }\end{array}$ \\
\hline \multirow{2}{*}{ 2017-A } & $\begin{array}{c}\text { General } \\
\text { Population }\end{array}$ & 887 & 531 & $59.86 \%$ \\
\hline & $\begin{array}{c}\text { Affirmative } \\
\text { Action }\end{array}$ & 60 & 50 & $83.33 \%$ \\
\hline \multirow{2}{*}{ 2017-B } & $\begin{array}{c}\text { General } \\
\text { Population }\end{array}$ & 1359 & 863 & $63.50 \%$ \\
\hline & $\begin{array}{c}\text { Affirmative } \\
\text { Action }\end{array}$ & 166 & 143 & $86.14 \%$ \\
\hline \multirow{2}{*}{ 2018-A } & $\begin{array}{c}\text { General } \\
\text { Population }\end{array}$ & 1440 & 430 & $29.86 \%$ \\
\hline & $\begin{array}{c}\text { Affirmative } \\
\text { Action }\end{array}$ & 40 & 26 & $65.00 \%$ \\
\hline
\end{tabular}

TABLE VI

SCORES IN THE DIAGNOSTIC TEST OF NEW ENTERING STUDENTS TO EPN FOR THE SEMESTER 2018-B

\begin{tabular}{|c|c|c|c|}
\hline \multirow{2}{*}{$\begin{array}{c}\text { Population } \\
\text { Segment }\end{array}$} & \multicolumn{3}{|c|}{ Score } \\
\cline { 2 - 4 } & Average & Min. & Max. \\
\hline $\begin{array}{c}\text { General } \\
\text { Population }\end{array}$ & 33 & 14 & 54 \\
\hline $\begin{array}{c}\text { Affirmative } \\
\text { Action }\end{array}$ & 26 & 3 & 53 \\
\hline
\end{tabular}

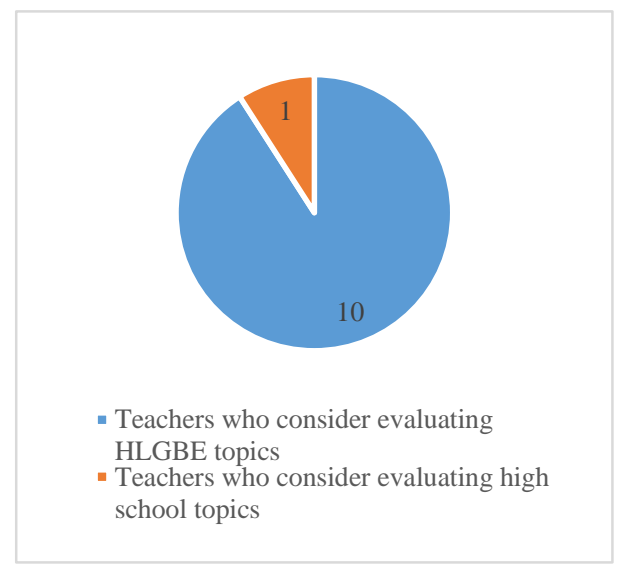

Fig. 2. Results of teachers surveys
When carrying out the ANOVA at a significant level of 0.05 , a p-value of 0.001 was obtained, as can be seen in Table VII. These results determine that the differences between groups were statistically significant and, therefore, the fact that if a student belongs to Affirmative Action population segment, this increases the probability that their knowledge in the evaluated topics will be deficient, in comparison with those of the General Population.

However, despite the fact that the results obtained for the PRTE by the students from General Population were higher than those obtained for Affirmative Action, the PRTE for the two groups, in general, presents relatively low values, which constitutes a disturbing result if one considers that students should master each of the evaluated topics, since they are part of the curriculum of the HLGBE.

The results of the PRUE are presented in Table VIII. Based on this information, it is proposed that the content of the Mathematics Pilot Program for engineering students from vulnerable groups should be structured in 6 units with special emphasis on Geometry and Trigonometry, and real-valued functions, since these are the topics in which the students presented the greatest shortcomings.

Table IX presents the proposal of Mathematics Pilot Program for engineering students from vulnerable groups. The pertinent topics are specified for each of the 6 units.

TABLE VII

ANOVA FOR PRTE OF STUDENTS FROM AFFIRMATIVE ACTION AND

\begin{tabular}{|c|c|c|c|c|c|c|}
\hline $\begin{array}{c}\text { Source of } \\
\text { variations }\end{array}$ & $\begin{array}{c}\text { Sum of } \\
\text { squares }\end{array}$ & df & $\begin{array}{c}\text { Mean } \\
\text { Square }\end{array}$ & F & p-value & F crit. \\
\hline $\begin{array}{c}\text { Between } \\
\text { groups }\end{array}$ & 0.3317 & 1 & 0.3317 & 11.371 & 0.001 & 3.932 \\
\hline $\begin{array}{c}\text { Within } \\
\text { groups }\end{array}$ & 3.0340 & 104 & 0.0291 & - & - & - \\
\hline Total & 3.3657 & 105 & - & - & - & - \\
\hline
\end{tabular}

TABLE VIII

PRUE OF STUDENTS FROM AFFIRMATIVE ACTION

\begin{tabular}{|c|c|}
\hline Unit & PRUE \\
\hline Geometry and Trigonometry & $35.21 \%$ \\
\hline Real-valued functions & $35.82 \%$ \\
\hline Operations with real numbers & $40.99 \%$ \\
\hline Special products and factorization & $41.71 \%$ \\
\hline Equations and inequations & $45.76 \%$ \\
\hline Operations with polynomials & $48.74 \%$ \\
\hline
\end{tabular}

$17^{\text {th }}$ LACCEI International Multi-Conference for Engineering, Education, and Technology: "Industry, Innovation, And 


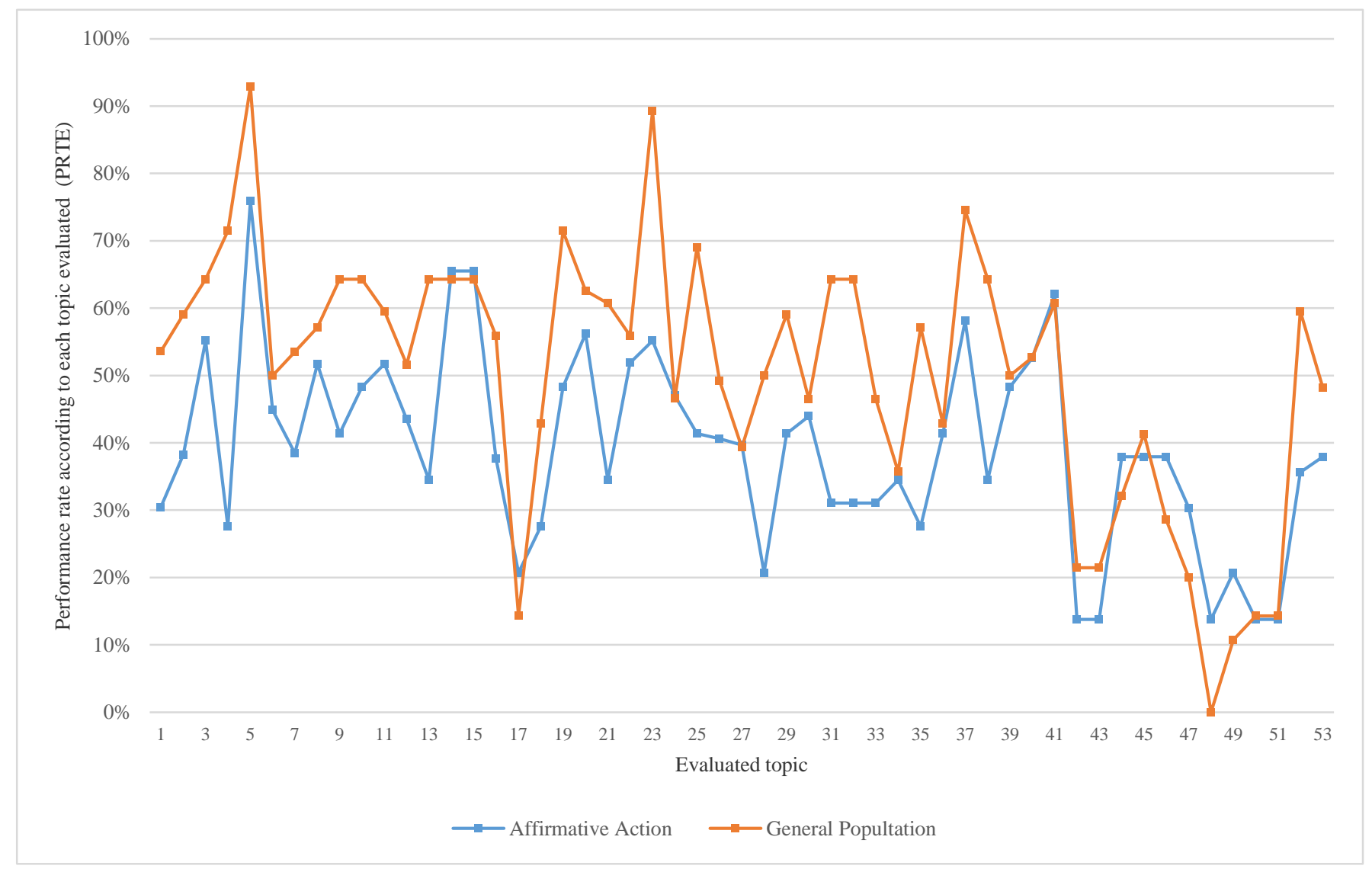

Fig. 3. PRTE of students from affirmative action and general population

TABLE IX

UNITS AND TOPICS OF MATHEMATICS PILOT PROGRAM FOR ENGINEERING STUDENTS FROM VULNERABLE GROUPS

\begin{tabular}{|c|}
\hline Units and Topics \\
\hline 1. OPERATIONS WITH REAL NUMBERS \\
\hline 1.1 Order relation for real numbers \\
\hline 1.2 Addition and subtraction of real numbers \\
\hline 1.3 Multiplication and division of real numbers \\
\hline 1.4 Absolute value \\
\hline 1.5 Operations with fractions \\
\hline 1.6 Least common multiple and greatest common divisor \\
\hline 1.7 Exponentiation \\
\hline 2. OPERATIONS WITH POLYNOMIALS \\
\hline 2.1 Addition of polynomials \\
\hline 2.1 Subtraction of polynomials \\
\hline 2.2 Multiplication of polynomials \\
\hline 2.3 Division of polynomials \\
\hline 3. SPECIAL PRODUCTS AND FACTORIZATION \\
\hline 3.1 Square of a binomial \\
\hline 3.2 Cube of a binomial \\
\hline 3.3 Common factor \\
\hline 3.4 Difference of squares \\
\hline
\end{tabular}

TABLE IX (Continued) Units and Topics

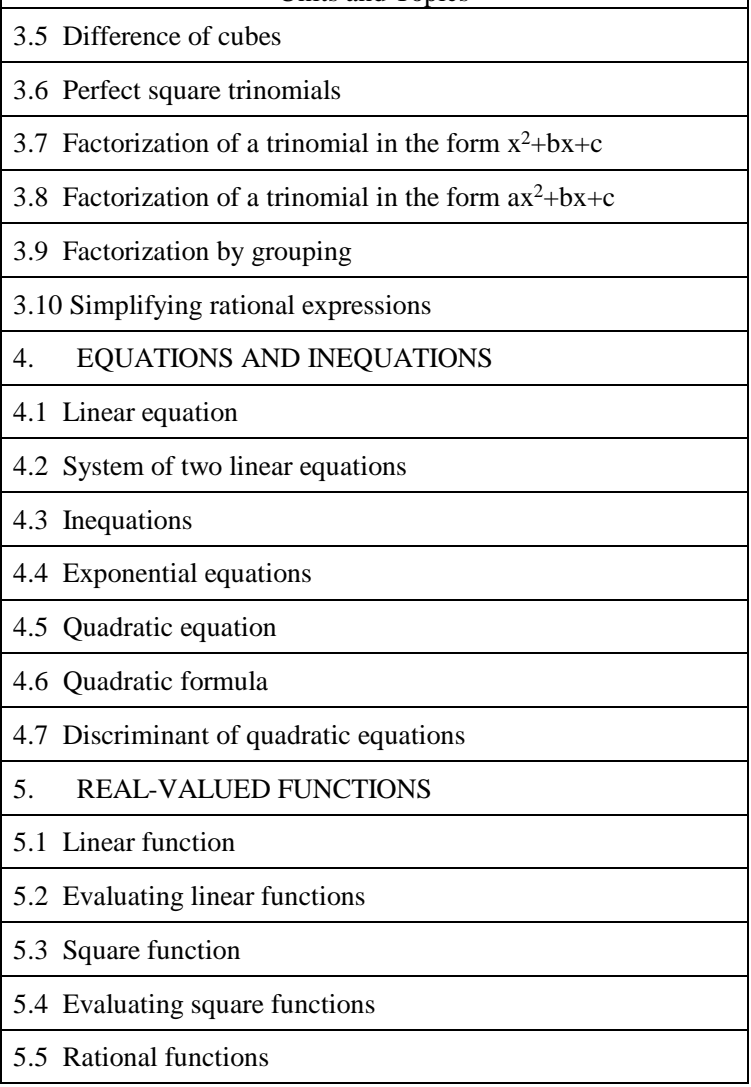

$17^{\text {th }}$ LACCEI International Multi-Conference for Engineering, Education, and Technology: "Industry, Innovation, And 
TABLE IX (Continued)

\begin{tabular}{|l|}
\hline \multicolumn{1}{|c|}{ Units and Topics } \\
\hline 5.6 Asymptote \\
\hline 5.7 Inverse function \\
\hline $6 . \quad$ GEOMETRY AND TRIGONOMETRY \\
\hline 6.1 Perimeter and area of regular polygons \\
\hline 6.2 Circumference perimeter and circle area \\
\hline 6.3 Volume of regular polyhedron \\
\hline 6.4 Angles \\
\hline 6.5 Complementary angles \\
\hline 6.6 Supplementary angles \\
\hline 6.7 Angles in parallel lines \\
\hline 6.8 Triangles \\
\hline 6.9 Angles in a triangle \\
\hline 6.10 Angle bisectors \\
\hline 6.11 Perpendicular bisectors \\
\hline 6.12 Pythagorean theorem \\
\hline 6.13 Trigonometric ratios in right triangles \\
\hline 6.14 Trigonometric ratios of special angles \\
\hline 6.15 Trigonometric identities \\
\hline 6.16 Conversion of units \\
\hline
\end{tabular}

\section{CONCLUSIONS AND RECOMMENDATIONS}

In general, during the semesters 2017-A, 2017-B and 2018-A, the students from Affirmative Action group showed poor previous academic preparation, due to the fact that the passing rate in the Leveling Course was lower compared to the one of the students from General Population.

The students from Affirmative Action group showed a greater dropping out rate than the students from General Population, during the semesters 2017-A, 2017-B and 2018-A. This dropping out, in its majority corresponds to an institutional dropout, since the students expire their maximum number of enrollments at EPN, however, premature dropout also has incidence, which makes reference to those cases in which the students, despite of having fulfilled the requirements validated by DGIP, did not formalize their enrollment and, in short, they did not link with the university.

The results of the diagnostic test showed that students from vulnerable groups have a deficient academic level and it is lower than that of the General Population, even more if it is considered that the diagnostic test evaluated knowledge of basic Mathematics. This fact correlates directly with the low academic performance and the high dropout rate that these students present during the Leveling Course.
The average of PRTE for students from Affirmative Action group was $39.2 \%$, while for students from General Population it was 50.4\%. However, despite the fact that the results obtained for the PRTE by the students from General Population were higher than those obtained from Affirmative Action group, the PPTE for the two groups, in general, presents relatively low values, which constitute a disturbing result if one considers that students should master each of the topics evaluated, since they are part of the curriculum of the HLGBE.

The fact that a student belongs to Affirmative Action group increases the probability that his or her knowledge in the evaluated topics in the diagnostic test will be deficient, in comparison with those of the General Population, which could lead to dropping out the Leveling Course.

It is proposed that the content of the Mathematics Pilot Program for engineering students from vulnerable groups should be structured in 6 units, with special emphasis on Geometry and Trigonometry, and real-valued functions.

The Government's Affirmative Action Policies are a valuable opportunity for students from vulnerable groups, however, in the case of EPN, they have become inefficient because there are no previous accompaniment programs that guarantee the retention of these students. It is recommended that the Mathematics Pilot Program should be implemented as a previous course to the regular Leveling Course of EPN, since from previous experiences it has been evidenced that carrying out an academic accompaniment program parallel to the Leveling Course is not effective.

It is recommended to apply a diagnostic test to new students for semesters 2019-A and 2019-B, with the aim of designing a robust admission model to improve the academic performance rates.

It is also suggested to carry out a study to develop an inclusive admission model for students from vulnerable groups, considering in addition to Mathematics, subjects such as Language and Communication, Computer Science and Technical Drawing, as fundamental subjects for engineering training. In the same way, it is recommended to include ICTs as support tools for the pilot program, as well as motivation and follow-up activities for students.

\section{ACKNOWLEDGMENT}

The authors thank the Escuela Politécnica Nacional for the financing of the project PIJ-17-12: "Implementación de un Curso Preparatorio Piloto para Estudiantes de Grupos Vulnerables - Política de Cuotas". 


\section{REFERENCES}

[1] SENESCYT. (2018, nov 10). Proceso de Admisión 2018 [Online] Available: http://admision.senescyt.gob.ec/soluciones/existe-puntajeminimo-ingresar-una-carrera/.

[2] I. Sandoval, T. Sánchez, V. Velasteguí, y D. Naranjo, "Factores Asociados Al Abandono En Estudiantes De Grupos Vulnerables. Caso Escuela Politécnica Nacional", CCLA, nov. 2018.

[3] SNNA, "Política de cuotas marzo 2017", Área de producción de la información, Quito, Ecuador, Informe Técnico Marzo, 2017.

[4] M.V. Di Caudo, "Política de cuotas en Ecuador: me gané una beca para estudiar en la Universidad", Ponto-e-Vírgula, vol. 17, pp. 196-218, 2015.

[5] C. Amo, y M. Santelices, "Trayectorias universitarias: MÁS QUE PERSISTENCIA O DESERCIÓN”, CCLA, nov. 2016.

[6] G. Montoya Gutiérrez, "Estudio Factores Asociados Al Abandono Temprano De La Educación Superior", CCLA, nov. 2016.

[7] H. Orozco Lara, J. Suarez Silva, M. Olarte Galeano, C. Cabanzo Carreño, y A. Beltran Ariza, "Estudio Factores Asociados A La Deserción Estudiantil En La Universidad Minuto De Dios De La Sede Virtual Y A Distancia", CCLA, nov. 2017.

[8] INEVAL. (2019, feb 20). Visualización de Resultados Ser Bachiller 2017-2018 [Online] Available: http://sure.evaluacion.gob.ec/ineval-dagivree-web-2.0-SNAPSHOT/publico/vree.jsf.

[9] M. Escalona Reyes, "El perfeccionamiento de la enseñanza de la Matemática en la educación superior. Su concreción en las carreras de ingeniería en la Universidad de Holguín", Revista Iberoamericana de Educación, vol. 56, no. 4, pp. 1-13, nov. 2011.

[10] L. E. González, Repitencia y Deserción Universitaria en América Latina. 2da ed. Santiago de Chile: Alfabeta Artes Gráficas, 2006.

[11] C. Diaz Peralta, "Modelo Conceptual para la Deserción Estudiantil Universitaria Chilena", Estudios Pedagógicos, vol. 34, no. 2, pp. 65-86, 2008.

[12] I. Sandoval, G. Prócel, J. Sánchez, I. Carrera, y A. Proaño, "Accompaniment program for university students from vulnerable groups at the Escuela Politécnica Nacional", 16th LACCEI International MultiConference for Engineering, Education, and Technology: "Innovation in Education and Inclusion”, 19-21 July 2018, Lima, Peru. 1

$17^{\text {th }}$ LACCEI International Multi-Conference for Engineering, Education, and Technology: "Industry, Innovation, And Infrastructure for Sustainable Cities and Communities", 24-26 July 2019, Jamaica. 